\title{
İskit, Asur ve Perslerin Siyasi ve Kültürel Farklılıkları Üzerine Bir Değerlendirme
}

\author{
An Evaluation on the Political and Cultural Differences of Scythian, \\ Assyrian and Persians \\ Suzan AKKUŞ MUTLU*
}

\begin{abstract}
Öz
İskitlerin Anadolu ve Mezopotamya'daki siyasi, askeri, kültürel faaliyetleri hakkındaki bilgilerimizi Asur, Urartu ve Pers kaynaklarından öğrenmekteyiz. M.Ö VIII. yüzyılda yaşanan şiddetli kuraklık sonucu ortaya çıkan kargaşadan dolayı Massagetlerle yaptıkları savaşı kaybeden İskitler, Kimmerlerin ülkesine gelmişlerdir. İçerde isyanlarla uğraşan Kimmerlerin bir kısmı İskitlerin de saldırısı sonucunda göç etmek zorunda kalmışlardır. İskitler bir süre onlarla birlikte yaşadıktan sonra göç eden Kimmerleri takip ederken yollarını şaşırarak Pers topraklarına ulaşmışlardır. Bu iki kavim önce Anadolu daha sonra Mezopotamya toplumlarının siyasî ve kültürel hayatlarını önemli ölçüde etkilemiş̧lerdir. Biz bu makalemizde, İskitler'e ait yazılı belgeler elimize geçmediği için ilişki içerisine girdikleri kavimlerin yazılı belgelerinden ve arkeolojik bulgulardan yola çıkarak, İskit, Asur ve Perslerin kültürel etkileşimlerini, farklılıklarını araştırarak, mukayese edeceğiz.
\end{abstract}

Anahtar Kelimeler: İskit, Mezopotamya, Asur, Pers, Kültür.

\begin{abstract}
We learn about the political, military and cultural activities of the Scythians in Anatolia and Mesopotamia from the Assyrian, Urartian and Persian sources. The Scythians who lost their war with the Massagets because of the turmoil caused by the severe drought in the VIII th century, came to the country of Cimmerians. Some of the Cimmerians who had engaged in insurrections had to migrate because of the attack of the Scythians. Scythians lived with them for a while after migrating to the Cimmerians who reached the Persian territory by surprise their way. These two tribes have influenced the political and cultural life of Anatolia and later Mesopotamian societies. In this article, we will compare the cultural interactions of Scythia, Assyria and Persians, based on the written documents and archaeological findings of the tribes that they have interact because we have not received written documents from the Scythians
\end{abstract}

Key Words: Scythians, Mesopotamia, Assyrian, Persian, Culture.

\section{Giriş}

Demir çağında Anadolu'ya giriş yapan İskitler hakkındaki bilgilerimizi maalesef onlara ait bir yazılı belge şu ana kadar bulunmadığı için arkeolojik bulgular ve ilişki kurdukları kavimlerin yazılı belgelerinden edinmekteyiz (Bkz: Şekil 1). ${ }^{1}$ İskit ve Kimmer akınlarından önce Doğu Anadolu'da hâkimiyet mücadelesi veren Asur ve Urartu ezeli iki rakiptir (Hrozny, 1953: 3). M.Ö. VIII. yüzyıl başlarında, topraklarını genişletme isteği karşı karşıya gelmelerine neden olmuştur. Fakat Kimmer ve İskit saldırıları Urartuların ve Asurluların arasındaki çekişmelerin son bulmasını sağlamıştır (Erzen, 1992: 37; Tellioğlu, 2005: 240). M.Ö. I. Bin yılda Asur Devleti'nin Anadolu'ya hâkim olma isteği İskit ve Kimmer akınları nedeniyle tam anlamıyla gerçekleşememiştir. Bu kavimlerin oluşturduğu tehlikeden dolayı Frig Devleti de Asur'a yaklaşmıştır (Sever, 2008:104,105; Memiş, 1999: 71,72; Memiş, 2012:131,132).

Türk kavimlerine karşı barışçıl bir siyaset izleyen Urartu kralı II. Rusa, İskitleri Manna topraklarından Asur üzerine yönlendirerek hem kendilerini tehlikeden korumuş hem de Asurlular güçlü bir düşmanla karşı karşıya gelmiştir (Çilingiroglu, 1997: 45). Hatta Taner Tarhan II. Rusa'nın ülkesinin yağmalanmasını engellemek için İskitlerle bir anlaşma bile yaptığını ileri sürmektedir (Tarhan, 1984: 113). İskitler, Manna ülkesine yöneldikten sonra, Manna Devleti de hem kendini bu istilacı kavimlerin akınlarından korumak hem de askeri

\footnotetext{
Dr. Öğr. Üyesi, Nevşehir Hacı Bektaş Veli Üniversitesi, Fen-Edebiyat Fakültesi, Tarih Bölümü, suzan.akkus@ @evsehir.edu.tr.

1 Asurluların kaynaklarında İskit adına ilk kez Asarhaddon (MÖ 680-668)'a bir belgege rastlanmaktadır. Belgede geçen “Gimirrai”lerin Kimmerler, Aşguzai”lerin ise İskitler olduğu bilinmektedir (Bakınız: ARAB II: 517).
} 
güçlerinden faydalanmak için bu kavimlerle ittifak yapmak zorunda kalmıştır (Dönmez, 2002: 40). Asur'a karşı kurulan bu ittifak Asur Kralı Asarhaddon tarafından M.Ö. 679 yılında bozguna uğratılmıştır (Tellioğlu, 2005: 242; Kınal, 1998: 258; Memiş, 2005: 43; Durmuş, 2008a: 35; Olmstead, 1964: 424). Ancak Asur'un hakimiyeti Kaaşaritu, Med, Manna ve İskitler tarafından kendisine karşı oluşturulan ittifakla sarsılmıştır (Palaz Erdemir ve H. Erdemir, 2010: 28). Asur kralı Asarhaddon (MÖ 680-668) İskitleri durdurmak için kızını İskit hakanı Bartatua ile evlendirse de kısa bir süre sonra yeniden saldırılara maruz kalmıştır (Çilingiroğlu, 1997: 104; Memiş, 2013: 211; Köroğlu, 2010: 177; Hasanaov, 2009: 8). Asarhaddon devrine (M.Ö. 680- 669) ait vesikalardan Prizma (B)'ye göre, Asur kralı devletin kuzey ve kuzeydoğusundan gelen kavimlerin saldırılarını etkisiz hâle getirebilmek için İskitlerle anlaşmak zorunda kalmıştır (Durmuş, 2008a: 4; ARAB II, No. 517; Durmuş,1997: 280). Ancak kısa bir süre sonra İskitler Asur Devleti'ne saldırmakla kalmamış, aynı zamanda bölgede Asur aleyhine ittifaklar kurmuştur. M. Ö. VII. Yüzyılın sonlarında yapılan İskit akınları, Asur Devleti'nin Urartular üzerindeki siyasi gücünü kaybetmesine neden olmuştur. Ancak Urartu Devleti de İskit saldırılarından nasibini almıştır. M.Ö. 585 yılında Urartular İskitler tarafından tarih sahnesinden silinmişlerdir (Smith, 1999: 70; Durmuş, 2008a: 85). Daha sonra İskitler, Asur'a karşı Medleri desteklemişlerdir. M.Ö. 652-625 yılları arasında bu ittifağa Manna ve Babilliler de katılmıştır. Düşman saldırıları karşısında eski gücünü yitiren Asur Devleti ticaret yolları üzerindeki hâkimiyetini de kaybetmiş̧tir (Palaz Erdemir ve H. Erdemir, 2010: 29; Günaltay, 1987: 112). M.Ö. 612'de Asur Devleti'nin y1kılmasından sonra ise İskitler M.Ö. VI. Yüzyılın ortalarına doğru Medlere destek vererek Babil'i yıkmalarına yardım etmiştir. Asur'un ve Babil'in yıkılması Mezopotamya'da Perslerin çok büyük bir siyasi güç olmalarını sağlamıştır (Tellioğlu, 2005: 2439). Tabiki Perslerin bu kadar güçlenmesindeki en büyük rol de İskitlere aittir (Bkz Şekil 2).

\section{İdari yapı ve askeri teşkilat}

Pers kaynaklarından farklı gruplara ayrıldıklarını öğrendiğimiz İskit Türkleri, çok geniş bir coğrafyaya yayıldıkları için tek bir hakan tarafından yönetilmeleri mümkün değildir. İskitlerin her grubunun başında bir reis vardır. Kabilelerin reisleri de yönetimde söz sahibidir. Farklı coğrafyalarda farklı hükümdarlar tarafından yönetilmelerine rağmen önemli durumlarda tek bir karar etrafında birleşmeleri aralarında bir birlik şuurunun olduğunu da göstermektedir (Durmuş, 2008a: 41,42; Memiş, 2005: 35). İskit devlet teşkilatında yönetim babadan oğula geçse de kurganlardan yöneticilerin fiziksel olarak güçlü, uzun boylu kişiler oldukları anlaşılmaktadır. Dolayısıyla hakanın eğitimli, zeki bir kişi olmasının yanında fiziksel görünüşünü de oldukça önemlidir (Durmuş, 2008a: 42). Mecliste söz sahibi olan, elçilerin kabulünde hazır bulunan İskit kadını ise yeri geldiğinde yönetime katıldı̆̆ı gibi erkeklerle birlikte savaşlara da dâhil olmaktadır. Yine Saka gruplarından olan Massagetler'in hükümdarıTomris'in bir kadın olması, kadınların devlet başkanlığı yapabildiklerinin de kanıtıdır (Durmuş, 2013: 54-57; Eroğlu, 2016: 444). Eskiçağda kadının statüsü toplumdan topluma farklılık göstermektedir. Antikçağ yazarları İskit kadınlarından genel olarak savaşta erkekleriyle birlikte mücadele eden cesur kadınlar olarak bahsetmektedir (P'yankov, 2002: 931).

İskitler askeri eğitime büyük önem vermişler, erkek çocuklarıyla birlikte kız çocuklarını da savaş için yetiştirmişlerdir. İskit kızları evleninceye kadar ata biner, savaşa katılır (Eroğlu, 2016: 444). Ancak ne Asur ne de Perslerde kadınlar savaşa katılmamaktadır. Yazılı kaynaklara dayanarak İskitlerde olduğu gibi Asur ya da Perslerde kadınların devlet yönetmediklerini söyleyebiliriz.

Persler ise mutlak bir krallığa sahiptir. "Krallar kralı" ünvanını taşıyan kral, tanrı Ahuramazda'nın yeryüzündeki temsilcisi olarak kabul edilmektedir. Yetkileri sınırsız olmakla birlikte bir de danışma kurulu vardır. İskit ve Asurlularda olduğu gibi Perslerde de krallar en 
büyük yargıç ve ordunun baş komutanıdır. Krallık Asur'da olduğu gibi babadan oğula geçmektedir (Arslan, 2010: 43,44). Kralın oğlu yoksa kızının eşi yani damadının bile tahta geçme hakkı bulunmamaktadır (Kuhrt, 2012: 22-38). Veliahtlara ve soylulara küçük yaştan itibaren ata binmek, ok atmak ve dürüst olmak öğretilmektedir. Ayrıca tanrının buyruklarını yerine getiren krala karşı,doğruyu söylemek de küçük yaşlardan itibaren öğretilmektedir (Ksenophon, 1974: 45,46; Ksenophon, 1999: 43;Y1ldırım, 2004: 161,162; Arslan, 2010: 43,44). Pers Devlet teşkilatında kral olacak kişinin Akhamenid soyundan gelmesi gerekmektedir. Kralın meşruiyetinin halk tarafından kabul edilmesi için bu soydan geldiğini göstermesi zorunludur. Çünkü Akhamenid sülalesinin yönetici olarak tanrı Ahuramazda tarafından seçildiğine inanılmaktadır (Van de Mieroop, 2006: 338). Yani Persler'de İskit ve Asurlular da olduğu gibi iktidar tanrı kaynaklıdır. Pers kralları yazıtlarında Tanrı Ahuramazda'nın desteğiyle tahta geçtiklerini belirterek iktidarlarını dinle güçlendirmişlerdir (Van de Mieroop, 2006: 336; Kuhrt, 2007: 394). Pers kralı Darius'un Behistun Kitabesi'ndeki ifadeleri bu duruma güzel bir örnektir:

Ahuramazdanın bana sunduğu, şu güzel, atları ve insanları bol olan ülke, Ahuramazda ve ben kral Darius'un isteği üzerine hiçbir düşman karşısında titremeyecektir. (Ayata, 2011: 142-144).

Asur'da da kral tanrının yeryüzündeki temsilcisidir. Emirleri doğrudan tanrıdan aldıklarını belirten kralların tanrılar tarafından atandığına inanılmaktadır. $\mathrm{Bu}$ açıdan bakıldığında İskit, Pers ve Asurluların benzer bir anlayışa sahip oldukları görülmektedir. Yani siyasi iktidarlarını tamamen din ile desteklemişlerdir. Pers kralları gibi "büyük kral", "güçlü kral", "evrenin kralı" vs. çeşitli unvanlar kullanmışlardır. Ayrıca hem Pers hem de Asur kralları tanrılara hizmet eden en büyük din adamı ve orduları komuta eden baş komutandır. Asur Devleti'nde krallık babadan en büyük oğula geçmekle birlikte zaman zaman diğer çocukların da tahta geçtiği görülmektedir (Cancik-Kırschbaum, 2004: 138,139; Köroğlu, 2010: 182,183).

İskit, Pers ve Asurluların hakimiyetleri altına aldıkları bölgeleri yönetme biçimlerinde de farklılıklar bulunmaktadır. Persler II. Kyros Dönemi (M.Ö. 559-530)'nden itibaren hâkimiyetleri altına aldıkları bölgeleri, satraplıklara ayrılarak merkezden atanan Pers asıllı valiler tarafından yönetmişlerdir (Kuhrt, 2007: 412; Duran, 2015: 61,62). İskitler gibi çok geniş bir coğrafyaya hâkim olan Perslerin devletin bütünlüğünü korumak amaciyla yönetim şeklinde yenilik yapmak zorunluluğu hâsıl olmuştur. II. Kyros büyük bir sahaya yayılmış devleti idare etme açısından Mezopotamyalılardan etkilenmiştir (Balcer, 1993: 2,3). Ancak II. Kyros satraplıkları Mezopotamya'dan farklı olarak etnik kökene göre düzenlemesi oldukça ilginçtir. Kral ayrıca satrapları, nüfuzlu kişilerden seçmiştir. Böylece krallar satraplıkları kontrol edebilmiştir (Duran, 2015:65. Kaya, 2018: 161,165). I. Darius ile birlikte yönetimde değişiklikler yapılmıştır. Bazı satraplıklar birleştirilmiş ya da daha küçük satraplıklar yönetim sisteminden çıkarılmıştır (Casabonne, 2007: 26).

Doğunun bu üç büyük imparatorluğunun yaşam tarzlarında da bazı farklılıklar göze çarpmaktadır. Bu kavimlerin yaşam biçimleri devlet işleyiyişi ve savaş taktiklerinde de etkili olmuştur. Örneğin Persler ve Asurlular göçebe İskitlerden farklı olarak yerleşik toplumlardır. Asur kralları Pers kralları gibi sarayda yaşamışlar hem devlet işlerini saraydan yürütmüşler hem de günlük yaşamını burada geçirmişlerdir. Pers ve Asur kralları önemli görevlileri kraliyet ailesinden, üst sınıfa mensup olanlar arasından atamışlardır. Bunların dışında Asur'da hadım memurlar (şar eşi) haremdeki görevlerinin yanı sıra üst düzey görevlere de getirilmişlerdir. Kemalettin Köroğlu, Asur döneminin sarayları ve yönetim anlayışının Osmanlı Devleti gibi pek çok devlete model oluşturduğunu belirtmektedir (Köroğlu, 2010: 185). Göçebe kavimler ise savaş taktikleri açısından yerleşik toplumlara göre bazı avantajlara da sahiptir. Daha küçük birliklerle süratle hareket etmeleri yerleşik kavimler karşısında 
üstünlük elde etmelerini sağlamaktadır. Pers kaynaklarında üç farklı İskit grubunun liderleri Sakesphares, Homarges ve Tomris'in Pers kralı Darius savaş açtığında bir araya gelerek fikir alışverişinde bulunmuşlardır. Bu durum Asur ve Pes Devleti'yle karşılaştırıldığında İskitlerin farklı gruplardan oluşmalarına rağmen önemli bir durum karşısında birlikte hareket edebildiklerinin de kanıtıdır (Durmuş, 2008b: 209). Ayrıca göçebe kavimler bir bölgeye genelde yağmalamak amacıyla sefer düzenlerler. Ancak yerleşik toplumlar tarafından yapılan savaş sonrasında gerçekleşen yıkıntılar üzerinde yaşam devam etmektedir. Göçebe bir yaşam tarzına sahip olan İskitlerin yerleşik toplumlardan uyguladıkları askeri strateji açısından da farklı oldukları görülmektedir. Örneğin Pers kralı Darius, İskit ülkesine düzenlediği bir seferi sırasında İskitler, Perslerle savaşmamışlardır. Darius İskit hükümdarı İdanthyrsos'a elçi göndererek karşısına çıkarak savaşmasını istemiştir. İskit hükümdarı ise şöyle söylemektedir:

İranlı, işte benim kanaatim: Beni hiç kimse ne korkutabilir, ne de önünden kaçmaya zorlayabilir; senden de kaçtığım yok: Şimdiye kadar yapmış olduğum şey, barış zamanında da her zaman yaptığım şeydir. Neden hemen savaşa girmiyorum, onu da sana açıklayayım: Bizim ne kentimiz var, ne de bir tek dikili ağacımız ki, elden gitmesin ya da yakılıp yıkılmasın diye korkup hemen savaşa girelim; ama siz eğer ille de savaşmak istiyorsanız, bizim atalarımızın mezarları var; onları bulun, onlara el kaldırın, o zaman görürsünüz mezarlarımız için dövüşüyor muyuz, dövüşmüyor muyuz...(Herodotos IV: 124-127).

Heredotos'un verdiği bilgilerden de anlaşıldığı üzere göçebe yaşantının en ayırıcı niteliği kurganlardır. İskit kurganlarında bulunan silahlar, at ve araba koşum takımları kültürlerinin en önemli unsurlarıdır. İskit hükümdarı savaşması için tek neden olarak atalarının mezarlarını işaret etmektedir. İskitler, Persler ve Asurlular gibi kendi kültürlerini empoze etmek için de mücadele etmemişlerdir. Asur ve Pers kralları hâkimiyetleri altına aldıkları bölgeleri Asurlaştırma ve Persleştirme politikası gütmekle birlikte aralarında uygulama açısından büyük farklılıklar da görülmektedir. Pers Devleti’nin kurucusu Kyros'un farklı kültür ve inançlara aşina olması sonraki süreçte izlediği siyasetine etkisi büyük olmuştur (Daryaee, 2013:16,17). Perslerin hoş görülü bir politika izlemesi hakimiyet altına aldıkları bölgelerin halkları tarafından benimsenmelerini sağlamıştır (Günaltay, 1987: 257, 258). Özellikle yerel kültürü koruma, inançlara saygı göstermeleri, kendi kültürlerini benimesetmeye zorlamamaları Perslerin sevilmesini sağlamıştır. Ayrıca Pers dilini ve dinini diğer kavimlere empoze etmek için zorbalık yapmamışlardır (Brosius, 2006: 1,2; Snell, 1997: 99; Dandamaev,1989: 63-65; Van de Mieroop, 2006: 333). Asurlular ise bu konuda Persler kadar hoşgörülü olmamışlardır. İnsanları zorunlu olarak göç ettirme politikasını uygulamışlardır. Fethedilen bölgelerdeki insanları sürgüne gönderip bu bölgelere Asurluları yerleştirmeye çalışmışlardır (Bkz: Şekil 3-5) (Cancik-Kırscbaum, 2004: 86). Ayrıca Asur kralları düşmanlarına yaptıkları zulmü yazıtlarında övgüyle anlatmışlardır. Örneğin; Asur kralı II.Asurnasirpal (M.Ö.883-859) Anadolu'ya yaptığı seferini anlattığı krali yazıtında yaptığı zulümden övgüyle bahsetmektedir:

Kent kapısının karşısına bir sütun yerleştirttim ve bütün elebaşların derisini yüzdürttüm...Sütunu derileri ile kaplattım...Kimini sütuna çaktırttım, kimini de kazı̆̆a geçirttim....Ve komutanlarının kol ve bacaklarını kestirttim. Tutsak alınanların çoğunu yaktırttım...Kiminin ellerini, parmaklarını kestirttim, kiminin gözlerini oydurdum. Genç kızları ve delikanlıları canlı canlı yaktırdım...(Sever, 2008 :82).

Bir başka Asur kralı III. Salmanassar (M.Ö. 858-824) da Huubuškia üzerine yaptığı seferini anlattığı yazıtında bölge halkına çok acımasızca davrandığından şöyle bahsetmektedir:

“...Kute kabilesinin geniş ülkesini veba, kötülük tanrısı Girra gibi tahrip ettim. Arzaškun’dan Gilzanu'ya, Gilzanu'dan Hubuškia'ya uzanan topraklar üzerine firtına tanrısı Adad gibi gürledim. Urartu üzerine merhametsiz egemenliğimi kurdum" (ARAB, I, No. 619).

Asur kralı Asurbanipal (M.Ö. 668-631)'in, Urartu kralı Aramu’ya karşı yaptı̆ğ zulmü anlattığı yazıtını da Asur krallarının düşmanlarına karşı nasıl acımasızca davrandıklarına dair bir başka örnek olarak verebiliriz: 
Ben Asur kralı Asurbanipal. Urartu kralı Rusa bana selamlar göndermiști. Elam elçileri, Nabu-Damik, Umbadara....önlerine koyduğum küstahça mesajı...(hem de) onların gözünde Dunnanu'nun ikinci oğlu Mannuki-ahe, onun şehrinin üzerindeki adam, Nabu-usalli'nin dillerini kestim, derilerini yüzdüm. (ARAB, II, 1046).

Antik dönem yazarlarından Heredotos'un verdiği bilgilere göre tıpkı Asurlular gibi İskitlerin de hakimiyetleri altına aldıkları bölgelerde hoşgörülü olmadıkları anlaşılmaktadır. Heredotos eserinde şöyle söylemektedir:

Asya, yirmi sekiz yıl Skythlerin boyunduruğu altında kaldı, ağır vergilerle, ilgisizlikle bütün ülke bir yıkıntı yerine çevrildi. Halktan haraç olarak topladıkları az geliyor, akınlar yapıyor, herkesin elinde ne varsa zorla alıp götürüyorlardı. (Heredotos I, 106).

Strabon ise İskitlerin dürüst ve adil insanlar olduklarını, bu yönleriyle de diğer kavimleri gölgede bıraktıklarını söylemektedir. Antikçağ yazarları arasındaki bilgi farklılıklarının ise dikkat çekmek için bu tür ifadeler kullandıklarını söylemektedir (Strabo, 1854: 464,467).

İskit, Asur ve Perslerin siyasi açıdan olduğu gibi askeri açıdan da farklı yönlerinin olduğu arkeolojik bulgular ve yazılı kaynaklardan anlaşılmaktadır. Örneğin; İskit ordusu büyük oranda süvarilerden oluşmaktadır. En önemli silahları yay ve oktur. Atlarında eyer kullanan ve çok iyi ata binen askerler hızlı manevra kabiliyetine sahip oldukları için uzak mesafeden savaşmayı tercih etmişlerdir (Herodotos; IV: 46; Durmuş, 2008a: 43). Kaynaklardan İskitlerin zehirli yılanlar kullanarak yaptıkları zehire kanca uçlu oklarını buladıklarını ve düşmana korku saldıklarını öğrenmekteyiz (Durmuş, 2008a: 48). At üzerinde kolay kullanılabilmesi için tasarlanan İskit yayı, ortalama $1 \mathrm{~m}$. boyunda, düz veya içe doğru kıvrık bir "beden" ile buna raptedilmiş iki kısa koldan ibarettir (Tarhan, 2002: 602,603). İskitlerin kullandıkları diğer silahlar kılıç, balta, mızraktır. Erkeklerle birlikte kadınlarının da ata binip, ok attıkları ve çok iyi birer savaşçı oldukları bilinmektedir (Durmuş, 2008a: 48). Ön Asya coğrafyasında askeri bir güç olarak ortaya çıkan İskitler karşısında mağlubiyete uğrayan kavimler onların askeri stratejilerini gözlemleme ve silahlarını öğrenme şansına sahip olmuşlardır. Mezopotamya ve Anadolu kavimleri İskitleri ordularında istihdam etmişlerdir. Arkeolojik kazılar sonucu Ön Asya'nın pek çok bölgesinde ortaya çıkarılan kancalı iki ya da üç kanatlı ok uçları İskitlerin farklı kavimlerin silah ihtiyacını karşılamak için üretim yaptıklarını da düşündürmektedir (Palaz Erdemir ve H. Erdemir, 2010: 32; Memiş, 1987). Ancak İskit tipi okların yerel olarak üretilip üretilmediği ise kesin olarak netlik kazanmış değildir (Dönmez, 2002: 40). Bununla birlikte İskit tipi ok uçlarının Persler ve Asurlular tarafından da kullanıldığı bilinmektedir.

İskit ve Asur ordusunda olduğu gibi Pers temel askeri eğitimini ata binmek, okçuluk ve mızrak kullanmak oluşturmaktadır. Hafif ve geniş başlı Pers okları ince uçlu çubukların ucuna üçgen şeklinde bronzdan yapılmış uçlara takılarak yapılmıştır. Üzerine üç tüy takılarak okun dengeli bir şekilde hedefine ulaşması sağlanmıştır. Ancak Pers okları zırh ya da kalkan kullanan askerlerde çok etkili değildir. Perslerin kullandığı silahlar büyük oaranda Yunan, Mısır ve İskitlerden etkilenilerek yapılmıştır. Perslerin kullandığı silahlardan biri de İskitlere ait olan ve genelde demirden yapılan $34-35 \mathrm{~cm}$. uzunluğunda çift yüzlü kısa bir kılıç olan Akinakes'tir. Ondalık sisteme göre düzenlenen Pers ordusunun en önemli parçası ise süvari birlikleridir (Arslan, 2010: 43-51). Antikçağ yazarlarından Ksenophon, Pers ordusundaki tüm askerlerin savaşırken miğfer ve göğüs zırhı taktığı bilgisini vermektedir. Ayrıca tüm atların başları ve gögüsleri de at zırhıyla kaplanmaktadır. Ancak savaş sırasında sadece kralın miğfersiz olması ise düşmana meydan okumak anlamına gelmektedir. Ksenophon, bu tür bir meydan okumanın Perslerde bir savaş geleneği olduğunu söylemektedir (Ksenophon, 1974: 41). Asurlular ise oldukça ilginç bir savaş geleneğine sahiptir. Askerler savaşta öldürdükleri düşmanlarının kesik başlarını ordu yazıcılarına getirerek kaydettirmektedir. Böylece Asur 
askerleri öldürdükleri düşman sayısı oranında kral tarafından ödüllendirilmektedir (Bkz: Şekil 4). Elbette soylu bir düşman askeri öldürmenin mükafatı da daha büyüktür. $\mathrm{Bu}$ gelenek özellikle Asur kralları tarafindan ödüllendirme yöntemiyle desteklenmiştir (Kuhrt, 2007: 185). İskitler ise savaş taktiklerini Perslerden ve Asurlulardan daha iyi bir şekilde uygulamışlardır. İskit liderlerinden Tomris Hatunun, M.Ö. 528 y1lında büyük Balhan'da Perslere karş1 uyguladığı savaş taktikleri İskitlerin bu konuda çok başarılı olduklarının kanıtıdır. İskitler savaş sırasında uyguladıkları yöntemlerle Pers ordusunun önünü keserek yenilgiye uğratmışlardır (Durmuş, 2008b: 210).

İskit kadınlarının gerektiğinde savaşa katıldığı da arkeolojik bulgulardan anlaşılmaktadır (Durmuş, 2013: 52,53). Ancak antikçağa ait yazılı belgelerden yola çıkarak ne Asur ne de Perslerde kadınların savaşa katıldıklarına ve orduyu yönettiklerine dair bir bilgi olmadığını söyleyebiliriz. Daha önce belirttiğimiz gibi İskit kadını devlet yöneticiliği de yapmıştır. Ancak Asur ve Pers Devleti'nde devlet yönetimi erkeklere aittir. İskit kadının eskiçağın savaş aracı olan atı süratli bir şekilde kullanabilmesi, savaşa katılması, devlet yönetmesi Türk toplumunda kadına verilen değerin de bir göstergesidir. Ayrıca İskitler bu yönüyle Asur ve Persler ile kıyaslandığında daha avantajlı görünmektedir.

\section{Sosyo-Ekonomik hayat}

Bozkır kültürüne sahip olan İskitlerin ekonomisi hayvancılığa dayanmaktadır. Strabon, İskitleri at sütü içen, tekerlekli arabalarda yaşayıp zenginliklerden yoksun olan kimseler olarak tanımlamaktadır (Strabo, 1854: 453). İskit erkekleri savaşta olduğu zamanlarda, sürülerin güvenliği ve otlakların korunmasından kadınlar sorumludur (Eroğlu, 2016: 444). Bozkır erkeğinin günlük görevi ise hayvanların bakımı, at üzerinde sürüleri otlatmak ve avlanmaktır. Bununla beraber İskitler ziraatla ve ticaretle de aktif olarak uğraşmışlardır. M.Ö. IV. yüzyıl itibariyle tarım ürünleri Karadeniz'de kurulmuş ticaret kolonileri aracılığıyla ihraç edilmiştir (Durmuş, 2008b: 207). Asurluların en önemli ekonomik kaynağı da ticarettir. M.Ö. II. bin yılda Anadolu'ya gelerek yerli krallardan izin almak suretiyle yerli halkla yaklaşık 250 yıl sürecek olan bir ticari ilişki kurmuşlardır. Çivi yazılı tabletlerden Asur kadının da İskit kadını gibi çalışıp aileye ekonomik katkı sağladığı kadınların ticaret hayatında aktif bir rol oynadıkları anlaşılmaktadır (Günbattı, 1994: 191-193; Bayram, 2017: 23). Ancak Asurluların aksine, göçebe yaşam tarzı sayesinde İskitler zor coğrafi şartlarda yaşamlarını rahatlıkla sürdürebilmektedirler. Örneğin Asur Devleti'nin Anadolu'daki en büyük düşmanı olan Urartuların yaşadığı coğrafya dağlık ve engebelidir. Hayvancılığa uygun olmakla birlikte tarım yapılabilecek arazi oldukça azdır. Göçebe yaşam tarzına uygun olan Doğu Anadolu'da Asurlular tutunamazken, Heredotos'un verdiği bilgilere göre İskitlerin bölgede yaklaşık 28 sene hükmetmeleri bunun en güzel örneğidir (Herodotos, Tarih, IV, 1).

Asurlular ticarete büyük önem verdikleri için gelişmiş bir yol ağı sistemi kurmuşlardır. Ayrıca Asur kralları ticaret yollarına hâkim olmak için pek çok sefer düzenlemişlerdir. Savaşların sonunda aldıkları haraçlar ve ganimetler devletin ekonomisine önemli ölçüde katkı sağlamıştır. Persler ise kurdukları satraplıklardan vergi alarak ve ordunun ihtiyaçlarını karşılayarak ekonomik bir gelir elde etmişlerdir (Köroğlu, 2010: 208,209; Kaya, 2018: $159,160)$. Devletin her yerinde geçerli, altından yapılan ve sadece kralların basma yetkisi olan para sistemi kullanılmıştır. "Dareikos" adı verilen tek bir para sisteminin uygulanması ekonomiyi sistemetik bir hala getirmiştir. Gümüş ve bakırdan para basma yetkisi ise Satraplara ve yerli yöneticilere verilmiştir (Diakov ve Kovalev, 2010: 198). Düzenli bir posta teşkilatının olması, Asurlulardan etkilenerek oluşturdukları askeri ve ticari amaçlar için kullanılan gelişmiş yol sistemi satraplıklarla iletişimi kolaylaştırmıştır (Sevin, 2013: 10,11). Asurlular orduların da rahatlıkla kullanabileceği, tekerlekli arabaların geçmesine uygun yollar yapmışlardır. Savaş zamanlarında ordu için gerekli olan ikmal hizmetini de kolaylaştırmıştır. Barış zamanlarında ise ulaşım ve ticari malların taşınması amacıyla kullanılmıştır. Asur 
Devleti'nin yıkılmasından sonra bu yolların hâkimiyeti Perslerin eline geçmiştir. Persler Asurlulardan etkilenerek oluşturdukları yol sistemini daha da geliştirmişlerdir. Hem yol sistemi hem de haberleşme ağı açısından İskit ve Asurlulardan daha iyi olduklarını söyleyebiliriz. Heredotos Perslerin çok hızlı bir haberleşme şebekesine sahip olduklarını şöyle anlatmaktadir:

...yol, baştan sona değil, bir günde aşllabilecek bölümlere ayrılmıştır. Bunlar değiştirme yapabilmek için her bir günlük aralık başına bir tane hesabı ile adam ve at verilmiştir. Habercinin yolu en kısa zamanda almasına hiç bir şey engel olamaz, ne kar, ne yağmur, ne güneş ateşi ne de gece. Birinci ulak haberi ikinciye aktarır, ikinci üçüncüye ve böylece gider. ( Herodotos V: 52).

Göçebe yaşamın yerleşik hayata göre bazı zorlukları da bulunmaktadır. Yerleşik yaşam süren Asur ve Persler göç etmek zorunda değildir. Ancak İskit toplumu belirli zamanlarda tüm kabile ve boylar ile birlikte hayvanları otlatmak için başka bölgelere göç etmek zorunda kalmışlardır. Yaşlılar ve çocuklar arabalarda genç kadın ve erkekler ise at üzerinde göç etmektedir. Bozkır kültürüne sahip İskit toplumunda kadın siyasi ve sosyal hayatın her kademesinde yer almıştır. Göç sırasında kadınların arabalarda seyahat etmeleri kadına verilen değerin de bir göstergesidir (Durmuş, 2013: 51). At üzerinde seyahat eden erkekler sürüleri yöneterek göç kafilelerine öncülük etmekte ve yol göstermektedir. Çadırlar, yani "yurtlar" ise konaklama alanlarında kurulmaktadır. Daha öncede belirttiğimiz gibi Pers ya da Asurlular yerleşik hayata tabi oldukları için göç etmek zorunda kalmamışlardır. Göçebe hayat tarzına sahip olan toplumlar sürekli hareket etmek zorunda kaldıkları için yerleşik toplumlara göre daha aktif bir yaşam sürmektedirler.

Dini inançları açısından ise Pers ve İskitler tapınaklar inşa eden, tanrılarını insan biçiminde tasavvur ve tasvir eden Asurlulardan ayrılmaktadır (Cancik-Kırscbaum, 2004: 138141). Heredotos Perslerin inançlarıyla ilgili şöyle söylemektedir:

Tanrı heykeli, tapınak, sunak yapmak gibi şeyler bilmezler; hatta yapanlara deli derler, bu sanırım, onların tanrılara, Yunanlılar gibi insan biçimi yakıştırmış olmamalarından ileri gelir (Heredotos, I, 131).

İskitler her varlığın bir ruh taşıdığına, bir iyi bir de kötü ruh olduğuna inanmışlardır (Durmuş, 2008a: 50). Aslında benzer bir durum Perslerde de görülmektedir. Perslerin inancına göre de kâinat sürekli iyi ile kötü, gerçek ile yalan gibi zit unsurların mücadelesine sahne olmaktadır (Bkz: Can, 1968: 274-277, İznik, 1999: 17; Sweeney, 2008: 104,105).

Heredotos İskitlerin Ön Asya'ya gelmeden önce tek tanrı inancına sahip olduklarını, ancak Greklerin etkisi altında kalarak politeizmi yani çok tanrı inancını benimsediklerini ileri sürmektedir (Durmuş, 2008a: 51,52). Persler zamanında İran'da kabul görmüş inançlardan biri Mitraizmdir. Adını tanrı Mitra'dan almaktadır (Eliade, 2003:395; Bkz: İznik, 1999: 9-19). Aslında Heredotos, Perslerin daha sonradan Araplardan ve Asurlulardan Aphrodite'ye tapmayı da öğrendiklerinden bahsetmektedir. Aphrodite'ye Asurlular Mylitta, Persler ise Mitra adını vermişlerdir. Ayrıca Perslerin tanrılarına kurban sunmak için sunakları bulunmamaktadır. Kurbanın üzerine su saçmak gibi bir adetleri de yoktur (Heredotos, I, 131,132).

\section{Sonuç}

Temeli hayvancılığa dayalı bozkır yaşantısı, acımasız hayat şartları nedeniyle devamlı olarak mücadele etme zorunluluğunu gerektirmiştir. Yerleşik hayata mensup insanların ekonomisi tarım ve ticarete dayalı olduğu için göçebe yaşam tarzına oranla daha rahattır. Persler ve Asurlular evlerde yaşarken, İskitlerin evleri çadırlardır. Hayvanları için sürekli göç etmek zorunda oldukları için yaşamlarının büyük bir kısmı at üstünde geçmektedir. 
Kadınların, savaşta düşmanın eline geçmesini engellemek için kendilerini koruyabilecek seviyede eğitilmişlerdir. Asur ve Pers kadınlarından farklı olarak İskit kadının erkekler gibi giyinip, ata binip, savaştığı bilinmektedir. Persler, Asurlular ve İskitler ok, yay, mızrak gibi savaş aletlerini kullanmalarına rağmen teknik açıdan farklılıklar bulunmaktadır. İskit oklarının özellikleri Ön Asya coğrafyasına damgasını vurmuştur. Çift taraflı ok uçlarının daha etkili olması için yılan zehiri kullanmaları oldukça dikkat çekici bir savaş taktiğidir. İskitlerin kullandıkları yaylar da ortalama $1 \mathrm{~m}$. boyunda olup at üzerinde daha rahat kullanılması için tasarlanmıştır. Hızlı ve çevik İskit süvarisi kalkan kullanmayı pek tercih etmemiştir. Ancak yer savaşlarında düşmanla yakın mücadelelerde nadiren kullanmışlardır. İskitlerin Turan taktiği ya da kurt oyunu adı verilen savaş taktiğini çok iyi uyguladıkları yazılı belgelerden anlaşılmaktadır.

İskit Türklerinin kullandıkları silahlar ve savaş taktikleri ilişki kurdukları kavimlerin de dikkatini çekmiş, onları gözlemleyerek benzer savaş stratejilerini kullanmaya çalışmışlardır. Yazılı belgelerden Ön Asya'da pek çok kavmin İskitleri ordularında istihdam ettirdiği anlaşılmaktadır. Asur ve Perslerden ayrılan en önemli özelliklerinden biri de Türk kadınlarının da devlet başkanı olmasıdır. İskit kadını devleti yönetmekte gösterdiği başarısını savaş meydanlarında da sergilemiştir. Tomris Hatun'un Türklerin Turan taktiğini uygulayarak Persleri büyük bir bozguna uğratması bu duruma güzel bir örnektir. Perslerin de savaşçı ve askeri açıdan oldukça güçlü olduklarını da düşünürsek Tomris Hatunun askeri yeteneği daha iyi anlaşılacaktır.

Eskiçağ toplumları dini inançları açısından genel olarak çok tanrılıdır. Ancak Heredotos'un verdiği bilgilerden yola çıkarak İskitlerin Ön Asya'ya gelmeden önce tek tanrı inancına sahip olduklarını, Greklerin etkisi altında kalarak çok tanrı inancını benimsediklerini söyleyebiliriz. Bu da İskitleri Persler ve Asurlulardan ayıran bir başka özelliktir. Ancak farklılıkların yanı sıra benzer pek çok kültürel yönleri de bulunmaktadır. Zira aynı coğrafyada yaşamış, ilişki kurmuş toplumların karşılıklı olarak birbirlerinden etkilenmemeleri mümkün değildir. Kültürel etkileşim hiçbir zaman tek taraflı gerçekleşmemiştir.

\section{Kaynakça}

Arslan, Y. (2010). Perslerin yönetim politikası. (Yayınlanmamış yüksek lisans tezi), Konya: Selçuk üniversitesi SBE.

Ayata, E. (2011). Zerdüşt Avesta bölümler. 3. Baskı, İstanbul: Kora yayınları.

Balcer, J. M. (1993). A prospographical study of the ancient Persians Royal and Noble 550450 B.C., New York: Lewiston.

Bayram, S. (2017). Ortadoğu'daki en eski uluslararası ticaret ve esasları. Ortadoğu'ya bakış, Editörler: Victoria Bilge Yılmaz - Dr. Sayim Türkman. Ankara: Nobel Akademik yayıncilik, 21-36.

Brosius, M. (2006). The Persians. London and New York: Routledge.

Can, C. (1968). Zerdüştçülük, zerdüşt ve hukuk (avesta). Ankara Üniversitesi Hukuk Fakültesi Dergisi. 1(25), 273-288.

Cancik-Kırschbaum, E. (2004). Asurlular (tarih, toplum, kültür). Çev. Aslı Yarbay, İzmir: İlya yayınları.

Casabonne, O. (2007). “Akamenid İmparatorluğu büyük kral ve Persler”, Arkeoatlas, 6, 2035.

Çilingiroğlu, A. (1997). Urartu Krallı̆̆ı tarihi ve sanatı. İzmir: Yaşar eğitim ve kültür vakfı.

Dandamaev, M. A. (1989). A political history of the Achaemenid Empire. (Translated into English by W. J. Vogelsang). The Netherlands, Leiden: E. J. Brill.

Daryaee, T. (2013). Cyros the Great. Santa Monica: Afshar publishing.

Diakov, V. ve Kovalev, S. (2010). İlk çă̆ tarihi. Çev. Özdemir İnce, İstanbul: Yordam kitap.

Dönmez, Ş. (2002). Önasya'da İskitler. Türkler IV, Ankara: Yeni Türkiye yayınları, 42- 63. 
Duran, M. (2015). Satraplık sisteminin Pers yönetim teşkilatındaki yeri. SDÜ Fen Edebiyat fakültesi sosyal bilimler dergisi, 34, 61-86.

Durmuş, İ. (1997). Anadolu'da Kimmerler ve İskitler. Belleten. LXI/231, 273-286.

Durmuş, İ. (2008a). İskitler. Ankara: Genel Kurmay basımevi.

Durmuş, İ. (2008b). İskit İmparatorluğu'nun yıkılış nedenleri. Akademik bakış. 1(2), 199-214.

Durmuş, İ. (2013). Türk tarihinin öncüleri Bilge Kağan, Alp Er Tonga, Tomris, Mo-tun, Attila. Ankara: Akçağ yayınları.

Eliade, M. (2003). Dinsel inançlar ve düşünceler tarihi: taş devrinden Eleusis Mysteria'larına. Çeviren: Ali Berktay. İstanbul: Kabalcı yayınevi.

Eroğlu, E. (2016). Sosyo-ekonomik açıdan eski Türklerde kadının konumu. Uluslararası Sosyal Araştırmalar Dergisi. 9(45). 443-447.

Erzen, A. (1992). Doğu Anadolu ve Urartular. Ankara: TTK yayınları.

Günaltay, Ş. (1987). Yakın Şark II Anadolu-Ahamenişler istilasına kadar. Ankara: TTK yayınlar1.

Günbattı, C. (1994). Kültepe tabletlerine göre kadınların ticari faaliyetleri hakkında bazı gözlemler. XI. TTKB, 191-200.

Hasanov, Z. (2009). Çar İskitler. (çev. İlyas Topsakal). İstanbul: Türk dünyası araştırmaları vakfi.

Herodotos (2002). Tarih. Çev. Mümtekin Ökmen, İstanbul: Türkiye İş Bankası yayınları.

Hrozny, B. (1953). Ancient history of Western Asia, India and Crete. Berlin: Published by Artia, Prag.

İznik, E. (1999). Anadolu'da Mithra Kültü. Ankara Üniversitesi, SBE., (Yayınlanmamış yüksek lisans tezi), Ankara.

Kaya, M. A. (2018). Anadolu'da Pers Satraplıkları: Kuruluş, Yönetim ve etnik yapı. Cedrus VI, 159-179.

Kınal, F. (1998). Eski Anadolu tarihi. IV. Bask1, Ankara: TTK.

Köroğlu, K. (2010). Eski Mezopotamya tarihi. İstanbul: İletişim yayınları.

Ksenophon (1974). Anabasis onbinlerin dönüşü. Çev. Tanju Gökçöl, İstanbul: Hürriyet yayınları.

Ksenophon (1999). Yunan tarihi. Çev. Oktay Sinanoğlu. Ankara: TTK Yayınları.

Kuhrt, A. (2007). Eski Çă̆'da Yakındoğu yaklaşık M.Ö. 3000-330. C. II, Çev. Dilek Şendil, İstanbu: Türkiye İş Bankası Kültür yayınları.

Kuhrt, A. (2012). "Pers İmparatorluğu, Anadolu'da Persler”. Aktüel arkeoloji dergisi, Şubat 5 (25), 22-38.

Luckenbill D. D. (1926). Ancient records of Assyria and Babiylonia (ARAB I), I. Chicago: The University of Chicago Press.

Luckenbill D. D. (1927). Ancient records of Assyria and Babylonia (ARAB II), II. Chicago: The University of Chicago press.

Memiş, E. (1987). İskitler'in uyguladıkları harp taktikleri'nin diğer milletler üzerindeki etkileri ve günümüzdeki belirtileri. Türk Kültürü, S. 293, Ankara.

Memiş, E. (1999). Asur Devleti'nin Anadolu politikası. XII. Türk Tarih Kongresi, TTK. 6573.

Memiş, E. (2005). İskitler'in tarihi. Konya: Çizgi kitabevi.

Memiş, E. (2012). Eskiçă̆ medeniyetleri tarihi. III. Baskı, Bursa: Ekin kitabevi.

Memiş, E. (2013). Eskiçağ Türkiye tarihi. XII. Baskı, Bursa: Ekin kitabevi.

Olmstead, A. (1964). History Of Assyria. Chicago.

Palaz Erdemir, H. ve Erdemir, H. (2010). Güneybatı Asya ve Avrasya'da İskit askeri izleri. Tarih okulu, VII, 25-37.

P’yankov, I. V. (2002). “ Sakalar”. Türkler, Yeni Türkiye, Ankara, 922-939. 
Radner, K. (2011). "Mass deportation: the Assyrian resettlement policy", Assyrian Empire Builders,(http://www.ucl.ac.uk/sargon/essentials/governors/massdeportation). Erişim:18.02.2019

Radner, K. (2018). "Assur Kenti ve Assur Krallı̆̆ tarihine genel bir bakış",.Assurlular: Dicle'den Toroslar'a Tanrı Assur'un Krallı̆̆ı. K. Köroğlu, S.F. Adalı (ed.), Tüpraş Anadolu Uygarlıkları Serisi No.7, İstanbul: Yapı kredi yayınları.

Sevin, V. (2013). Anadolu'nun tarihi coğrafyası. Ankara: TTK Yayınları.

Sever, E. (2008). Asur tarihi. III. Bask1, İstanbul: Kaynak yayınları.

Smith, A. T. (1999). The Making Of An Urartian Landscape İn Southern Transcaucasia: A Study of Political Architectonics. America Journal of Archeology, 103(1), 45-71.

Snell, D. C. (1997). Life in the Ancient Near East (3100-332 B.C.E.). New Heaven and London: Yale University Press.

Strabo (1854). The Geography of Strabo Vol I. Çev. H. C. Hamilton- W. Falconer, Henry G. Bohn: Londra.

Sulimirski, T.ve Taylor, T. (1991). The Scythians. CAH, 3(2), John Boardman, I. E. S. Edward, N. G. L. Hammond (Edits.). Cambridge Universty Press. 547-590.

Sweeney, E. J. (2008). The Ramessides, Medes, and Persians. New York: Algora Publishing.

Tarhan, T. (1984). "Eski Anadolu tarihinde Kimmerler". Araştırma sonuçları toplantısı bildirleri. Ankara.

Tarhan, T. (2002). Ön Asya dünyasında ilk Türkler Kimmerler ve İskitler. Türkler Ansiklopedisi. IV, 597-610.

Taşkın, E. (1992). Eski Anadolu tarihinde Persler. Selçuk Üniversitesi, SBE., (Yayınlanmamış yüksek lisans tezi), Konya.

Tellioğlu, İ. (2005). Kimmer ve İskit göçlerinin Doğu Anadolu Bölgesi'ndeki etkileri. A. Ü. Türkiyat araştırmaları enstitüsü dergisi. 27, 237-245.

Van de Mieroop, M. (2006). Antik Yakındoğu'nun tarihi. Çev. Sinem Gül, Ankara: Dost kitabevi.

Yıldırım, R. (2004). Uygarlık tarihine giriş. Ankara: Asil yayın dağıtım. 


\section{Ekler}

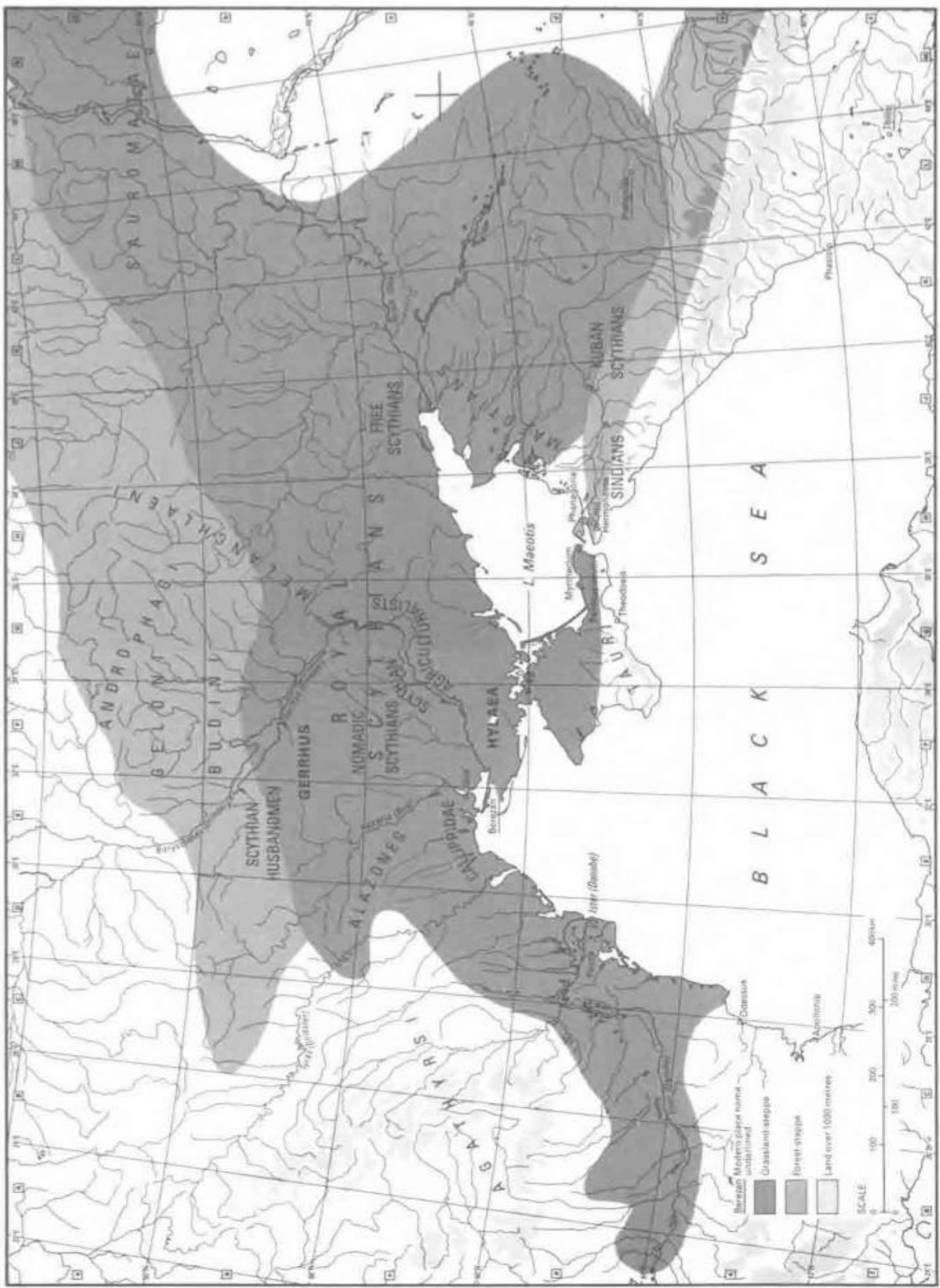

Şekil 1: İskit coğrafyası (Sulimirski ve Taylor, 1991: 548). 


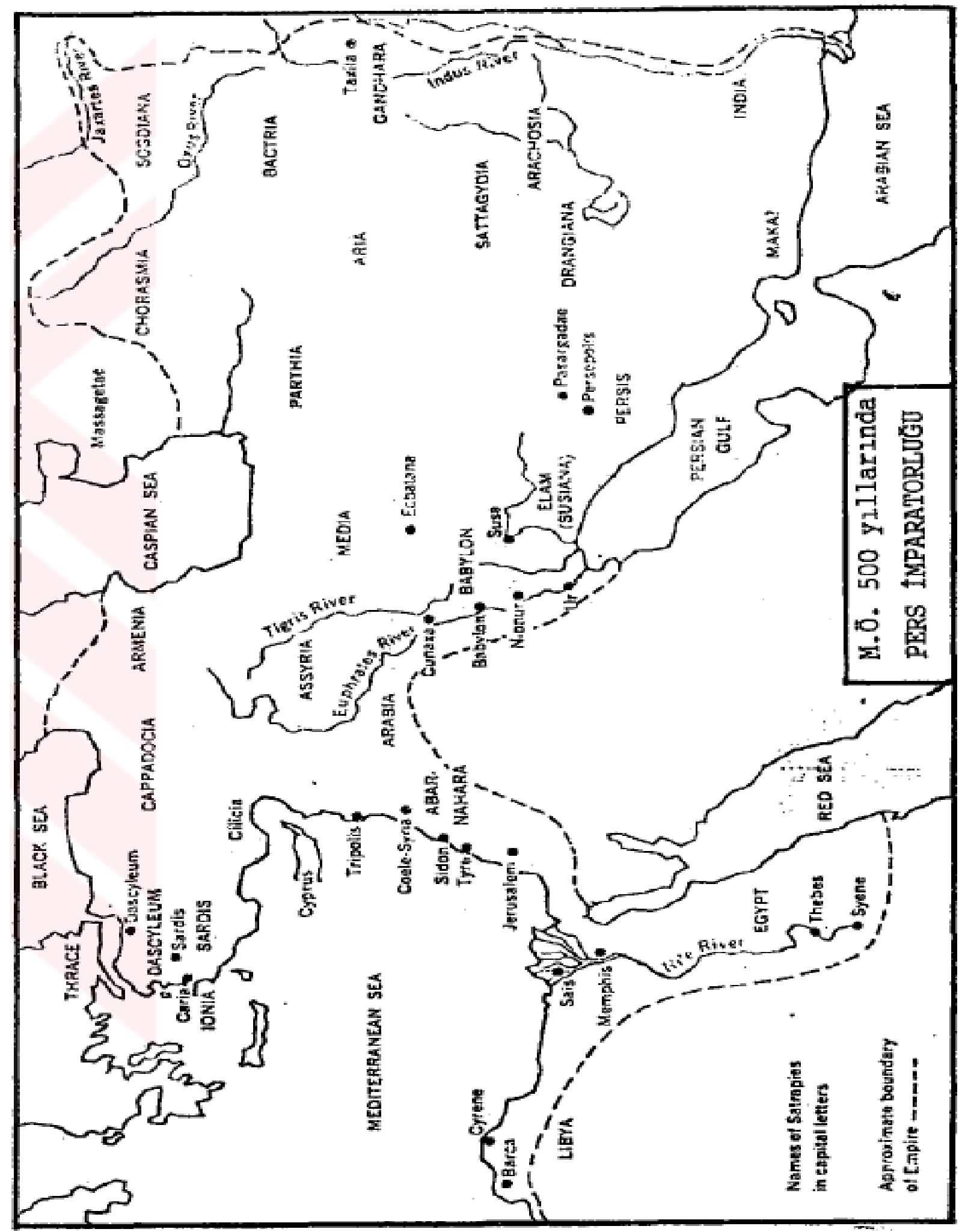

Şekil 2: M.Ö. VI. Yüzyıl ön Asya siyasi harita (Taşkın, 1992). 


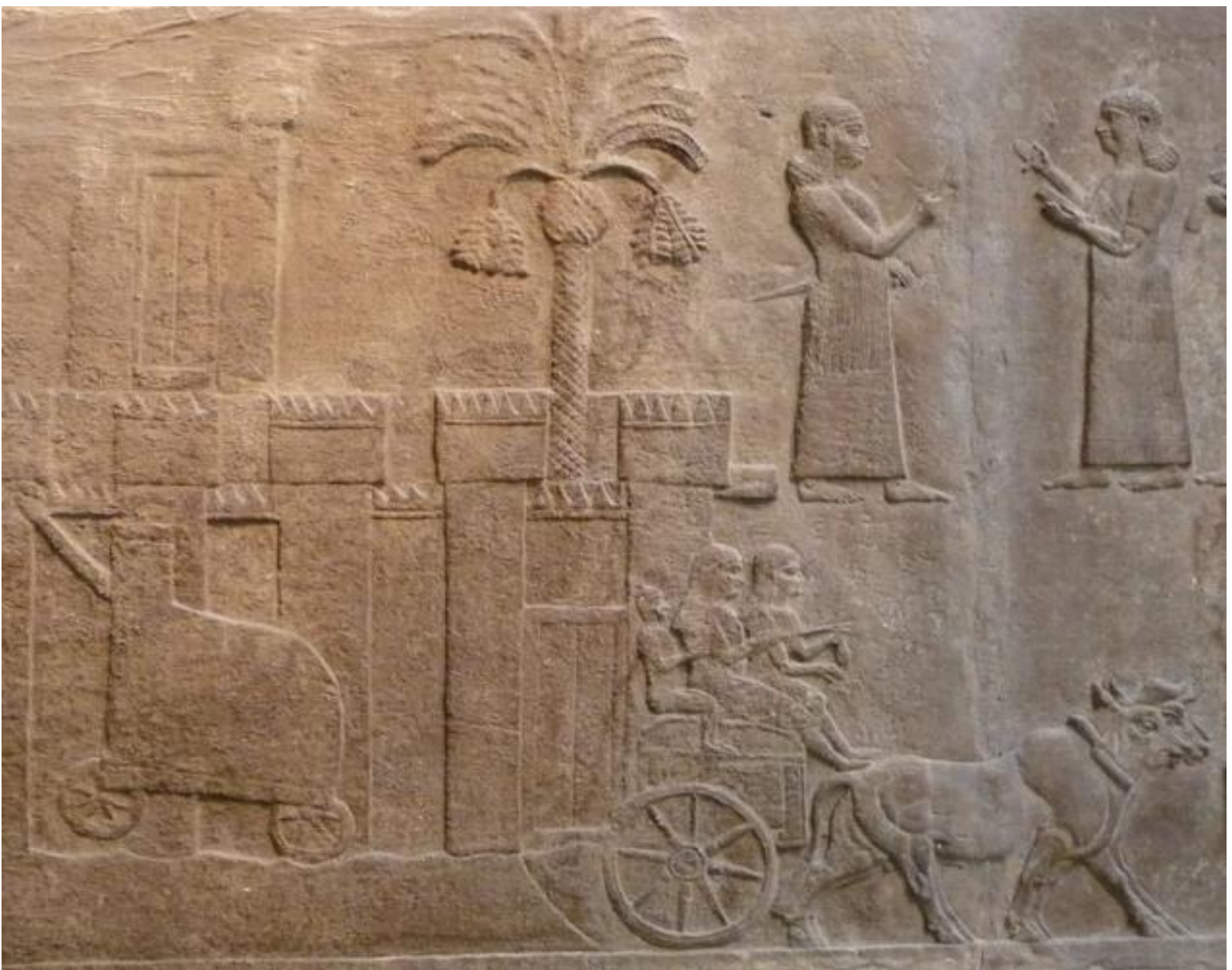

Şekil 3: Asur Kralı III.Tiglat-Pileser dönemi'nde gerçekleştirilen sürgün (Kalhu sarayı'ndan bir duvar kabartmas1) (Radner, 2011.)

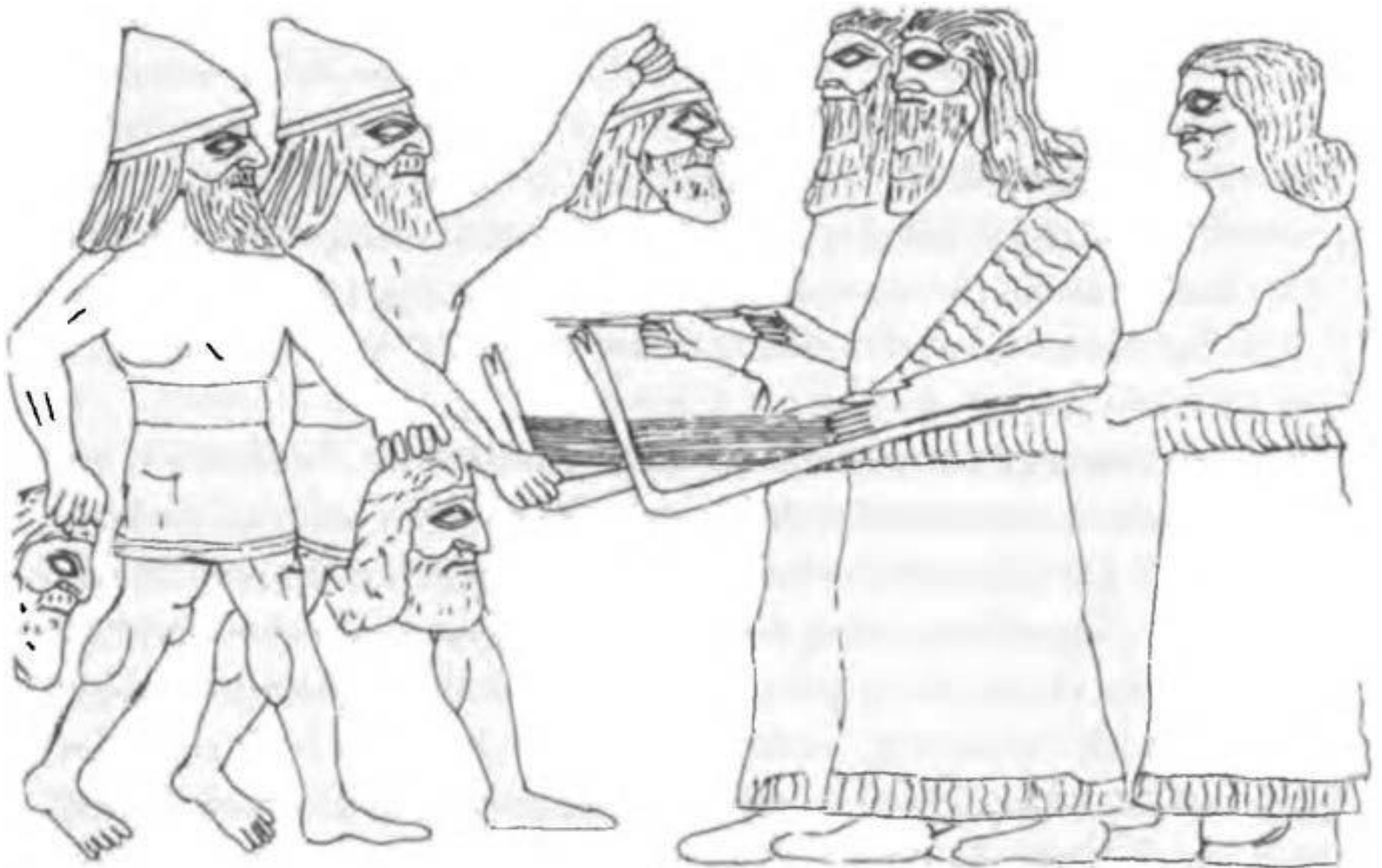

Şekil 4: Ellerinde düşmanların kesik başlarını tutan Asur askerleri (Kuhrt, 2007: 186). 


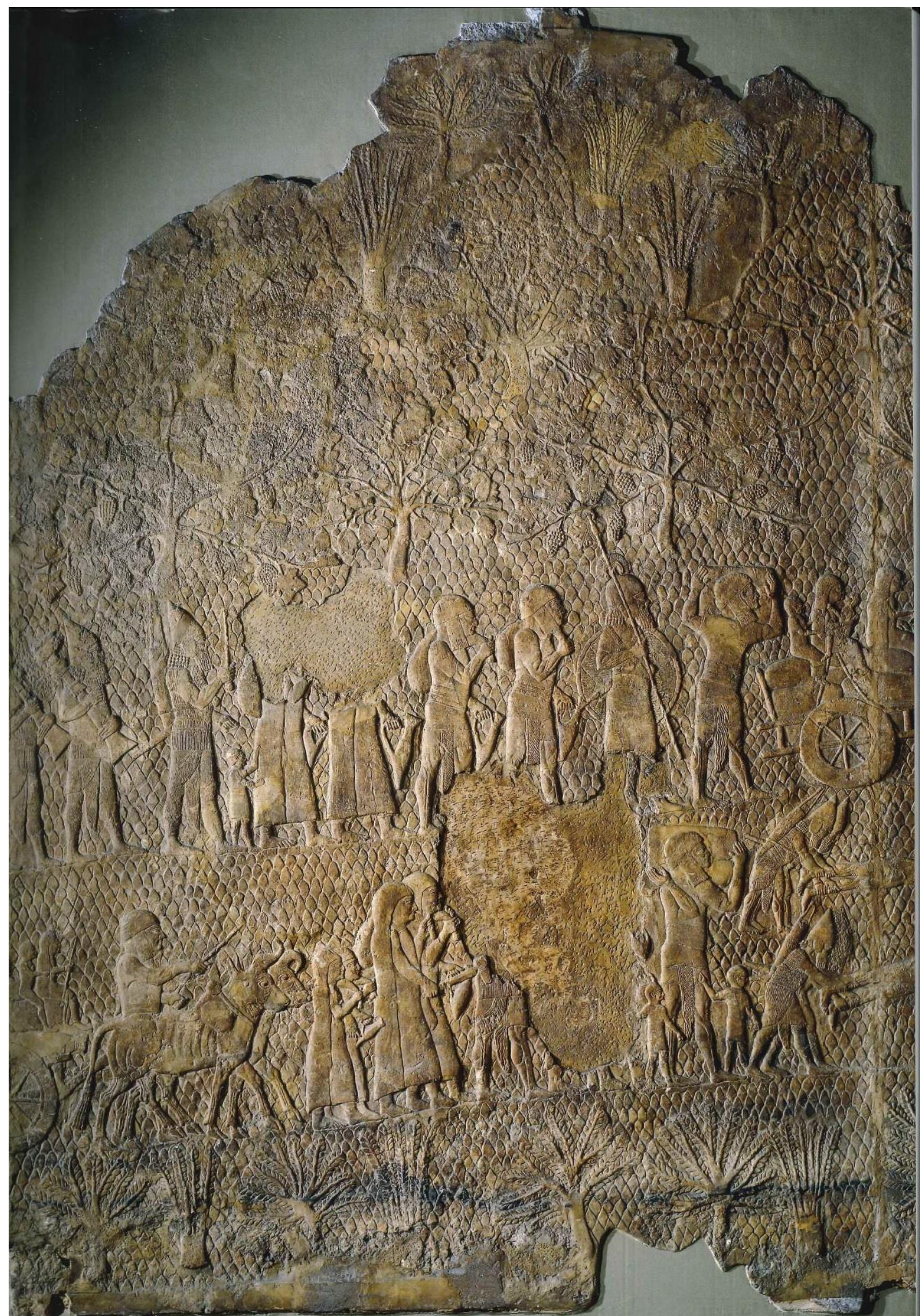

Şekil 5: Asur Kralı Sanherip döneminde gerçekleștirilen Lakiş kentinden sürgün edilenleri gösteren kabartma (Radner, 2018). 

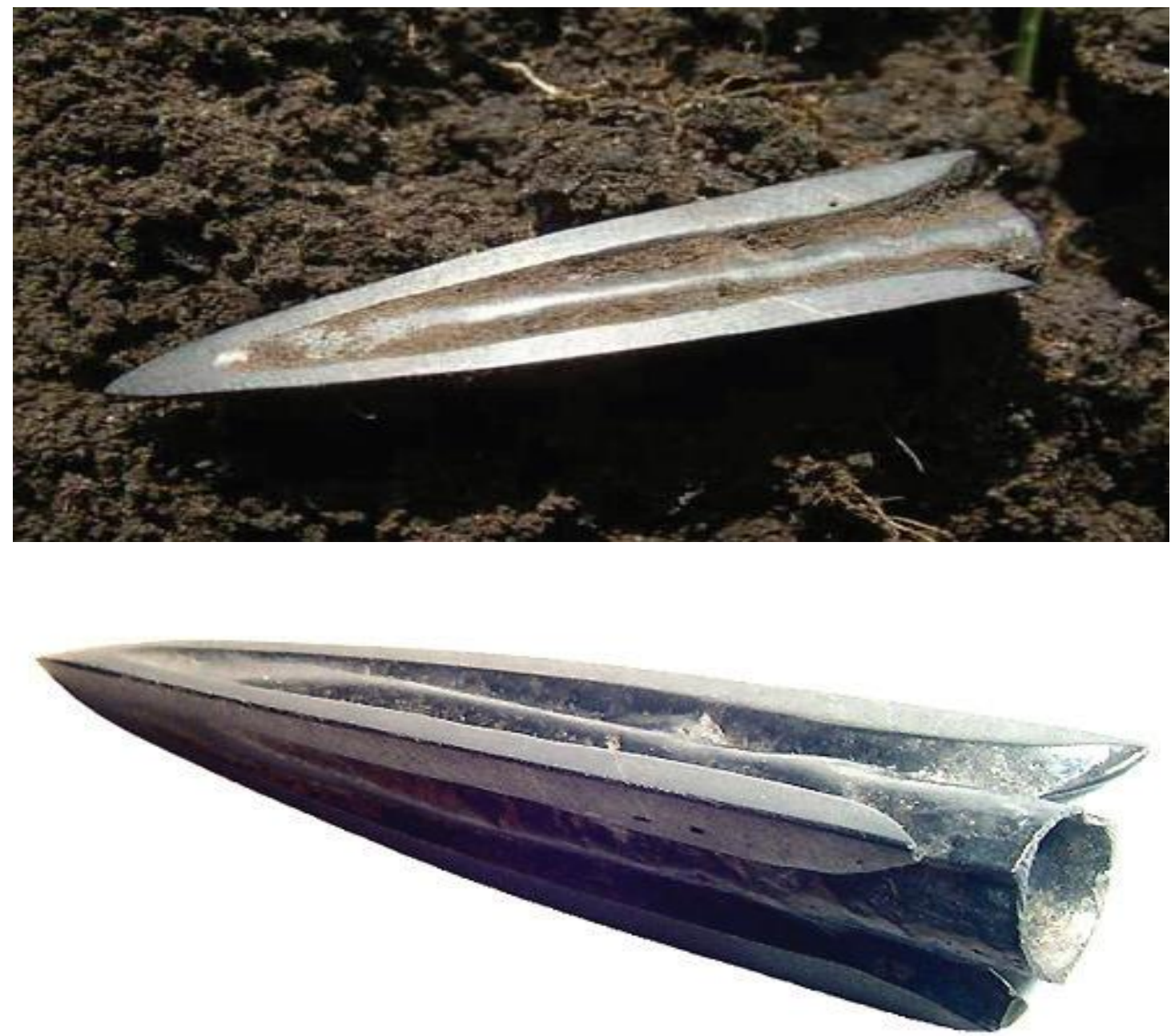

Şekil 6: İskit ok uçları (Palaz Erdemir ve Erdemir, 2010).

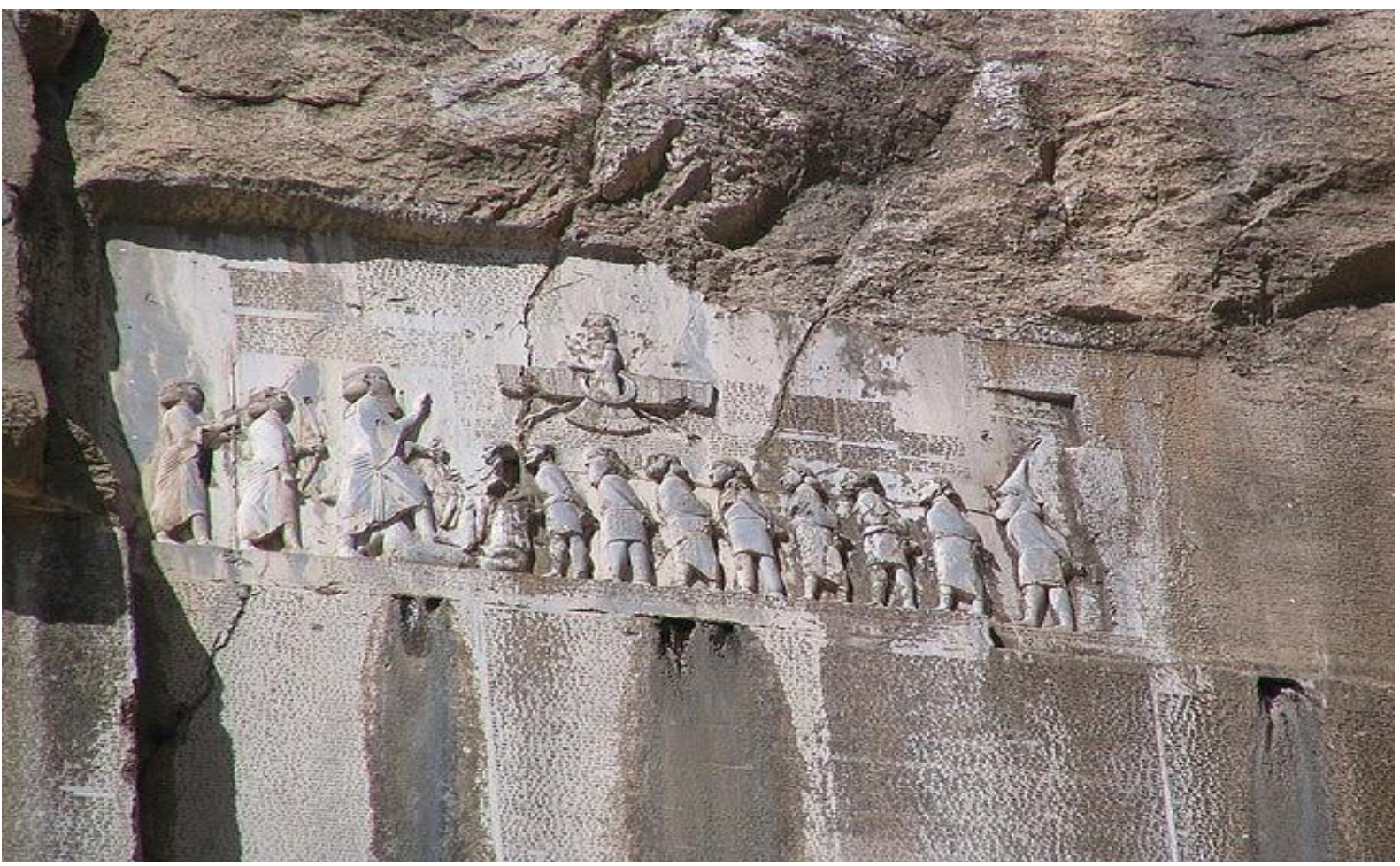

Şekil 7: Behistun kitabesi (Kuhrt, 2012). 